\title{
Quality assurance in broadcast style and content in Nigeria
}

\author{
Rowland U. Aleshi \\ Federal College of Education, Obudu-Cross, River State, Nigeria
}

\begin{abstract}
People's voices are critical instruments in the development and sustenance of any society. In this era of democracy there is need for quality assurance in broadcast style and content in order to communicate government policies to the people as well as elicit and encourage Nigerians to ensure sustainability on issues such as nation building. To maintain standards in broadcast content and presentation, the language and accent of broadcast programming should reflect and interpret the people's interests, and make important contributions to the development of the cultural heritage and economy of the society. Quality assurance in broadcast style and content should fulfill social and cultural needs of the people through decent programme offerings that have good taste for public interest. The writer recommends that broadcast producers should uphold editorial values and maintain technical and artistic standards to promote and preserve quality assurance in broadcast style and content in Nigeria.
\end{abstract}

Keywords: Quality; Assurance; Broadcast; Style; Content

\section{Introduction}

Since the 1930s, when the British Empire Broadcasting Service of the colonialists floated the relay re-diffusion system in which subscribers had access only to channels on or off on their radio sets, broadcasting, the transmission through space by means of radio frequencies of signals capable of being received either aurally or both aurally and visually by the general public has metamorphosed from colonial government monopoly in Nigeria into regional governments' domination. According to Duyile, (2004), in late 1950s and early 1960s, broadcasting has passed through the era of Federal Government annexation and monopolization to contemporary liberalization that accommodates private participation. Momoh, (2002) notes that; like other segments of society, media reflect the population of the people. Broadcast stations provide contents to audiences in English. A multiplicity of media voices can be found in Nigeria largely because of the diversity of the population of the country and the history preceding its independence. The large number of different voices created something of a marketplace of ideas. Such ideas and voices are to be articulated to promote the unity and diversity of Nigeria (Salihu, 2004),

In this era of democracy where freedom of information, the rule of law, assertion of human rights, empowerment and development of the people at the grassroots thrive, there are competing influences and interests on how the broadcast media construct legitimacy for the Nigerian people. Agbaje, (1998) cited in Oketunmbi (2007), describes it as a "battlefield of representations. "Engaged in this battlefield are such segments of society as the competing power bases, the educational system, the work environment, popular culture, the mass media, the languages of the various groups, sports, and other competing forms of entertainment. Agbaje 
goes on to describe the problem being exacerbated by the colonial heritage and non-Africans trying to explain the realities of the nation's complex social structure. Various cultural, religious, and tribal groups continue to be at odds over how the country should be governed. Even reaching an agreed political ideology signifies challenges to the various interest groups within the country. According to (Nwanwene, 2005), this ongoing battle can be seen throughout the country's history. Presently, there are political, economic and security challenges that threaten the very fabric of the nation. It is against this background that broadcast media are urged to disseminate messages that foster unity and peaceful co-existence in Nigeria.

\section{What is broadcasting?}

Over the last eighty or so years broadcasting has become an integral part of modern life. Through it we are witnesses to the secrets of the world, humanity's greatest achievements, inventions, as well as disasters. Due to the ever- expanding realms of digital technology and the proliferation of communications media, such as the internet, on-line newspapers and the like, it is increasingly difficult to pin down a precise definition of broadcasting. For the purpose of this paper, Goodwin (2000) defines broadcasting as communication between one person or organization with many others - point to multi -point through electronic delivery over the airwaves.

Mr. John Reith, the first Director-General of the BBC, which was founded in 1922 and which became a public corporation in 1926, said his idea of public service broadcasting involved a mission to " inform, educate and entertain" every citizen -to uplift them morally and culturally, and to represent a single national culture.

\section{The History of Broadcasting in Nigeria}

From 1932, when Radio Broadcasting Service started in Nigeria, as Empire Service of the British Broadcasting Corporation (BBC) to 1992 when Broadcasting in Nigeria was deregulated, the broadcast media were owned either by the National, Regional or State Governments.

The Federal, Regional and State governments continued to monopolize broadcasting in Nigeria, despite the 1979 constitutional provision "that every person shall be entitled to own, establish and operate any medium for the dissemination of information, ideas and opinion," which included the broadcast media.

It was not until the promulgation of Decree 38 of 1992, under the leadership of General Babangida, now an Act of the National Assembly that Government really took a decisive step to part with its long-drawn monopoly of the broadcast sector. That decree established the National Broadcasting Commission and charged it with the responsibility of regulating and deregulating broadcasting in the country. The law empowered the Commission to license stations, regulate content and, generally, set standards for quality broadcasting in the country.

Expectedly, the emergence of the Commission heralded a wave of requests from the Nigerian entrepreneurs for broadcast licenses that would enable them to set up private broadcasting stations in the country. This has changed the broadcast landscape tremendously, as it allowed the ownership of radio and television by private companies and organizations in the country.

By the middle of 1992, 27 broadcast licenses, 14 for terrestrial television and 13 for cable television, received presidential approval. Although not all those whose applications for license were initially approved took advantage of the approvals, leading to the lapse of such unutilized 
approvals, many more licenses were subsequently approved for applicants, including those for radio and DTH transmissions.

Today, as a result of that revolution in the Nigerian broadcast industry, the number of broadcasting stations in the country has, at the last count, risen to 394, from less than 30 before deregulation. These include the following number of Private Operators in the broadcast arena:

- 55 companies licensed to offer radio broadcasting services, over $90 \%$ of these are operational across the country.

- $\quad 25$ companies licensed to offer television service.

- $\quad 34$ Wireless Cable (MMDS) Companies.

- 5 Direct to Home (DTH) Satellite Television Platforms operational in the country.

Definition of Quality Assurance: According to Oxford Advanced Learner's Dictionary (2010), quality assurance is the practice of managing the way goods and services are provided to make sure they are kept at a high standard. Rouse (2007) defines quality assurance as follows: in developing products and services, quality assurance is any systematic process of checking to see whether a product or service being developed is meeting specified requirements. Many organizations have a separate department devoted to quality assurance. A quality assurance system is said to increase customer confidence and an organization's credibility, to improve work processes and efficiency, and to enable an organization to better compete with others. Quality assurance was initially introduced in World War II when munitions were inspected and tested for defects after they were made. Today's quality assurance systems emphasize catching defects before they get into the final product.

This is why this paper is concerned with the defects, flaws and lapses in broadcast style and content so that listeners and viewers confidence and enjoyment are guaranteed. But the media are generally seen to pander to the needs and aspirations of the elites in the society. The Media Institute of South Africa (MISA) states that there is a need for a paradigm shift to participatory and dialogue journalism by talking more to other listeners and viewers, and talking less to newsmakers. This new experience can make listeners and viewers become partners in the process of exploring solutions while exposing problems.

We can seek to extend the work of the broadcast media through quality assurance in broadcast style and content. This can be done by taking in to account the concerns, problems, needs and worries of ordinary citizens and getting real people's voices in to stories to, "reflect the pluralism of 'the world out there', based on realization that the points of views available within media may not be broad or comprehensive enough."

Even though the literacy level in Nigeria is still low, nowadays there are critical listeners and viewers who know how to deconstruct the broadcast media. So it is important for broadcasters to consider their audience and not take the arrogant view that they are creative professionals and know best.

From the foregoing, Goodwin (2000), states that the tasks and duties of broadcast journalists entail identifying, researching, recording, writing and sometimes presenting news stories and other programmes scheduled for the day's broadcast. Broadcast journalists are expected to acquire technical broadcast skills and a thorough understanding of copyright issues and the law as it affects journalists. Broadcast journalists require excellent written and verbal communication skills. They must have a pleasant voice and speak fluently and clearly (sometimes without a script or any preparation). They must be able to condense complex (and sometimes conflicting) information into concise, informative and interesting written reports. They must be logical, analytical and clear-thinking, and also possess good people skills. 
Broadcast journalists must be able to spot good stories, and they should be innovative, inquisitive and dynamic. They must have a broad knowledge of current affairs, at local and international levels.

Broadcast Style:The type of news content determines the style or delivery or presentation of the news. For example, a sports programme is presented in a racy, lively style in contrast to news broadcast that is structured in to segments, and the narrative format of a documentary.

Broadcast Content:This is the subject matter of a broadcast programme that is aired be it news or a talk show. For electronic media, content determines programming. There are exciting possibilities in content sharing among commercial stations in the broadcast industry. It is to be noted that broadcast media have important issues characterizing their content as well as their socio-political and economic relationship with the society.

Broadcast Programme:According to Sambe (2003), a programme is a message, which a broadcast medium offers to the society to justify the reasons for its existence or social function. Such a message must be broadcast on radio or television and is creatively and freely crafted not only to justify some taste but also to influence people or create awareness.

Onabajo (2001), defines a programme as a material created to meet certain specific needs or attain some set objectives, and transmitted to some predetermined target audience. He adds another dimension to the programme concept.Programmes produced on the broadcast media do necessarily have target audiences whom the programme builder predetermines (determines before the actual production of a programme). In other words, a programme is an individual performance designed for a particular or targeted audience, slated for a particular time in the broadcast media. Broadcast Programming: You cannot discuss quality assurance in broadcast style and content without mentioning programming because through successful programming, broadcasting must fulfill its social, cultural, economic, political, technological and professional objectives. Programming is the process of determining and scheduling of the contents of broadcast operations. Programming is the planning and execution of what radio listeners would hear, and what television viewers would see on their sets in a predetermined order. Programming is about the contents of radio and television signals that have increased in terms of varieties and durations. Clearly, quality assurance in broadcast style and content is the issue of what would be on air, when, and for how long?

The role of programming is crucial to successfully attract and hold the wavering attention of the audience to the medium. Successful programming depends on the audience for survival thereby attracting a large number of advertisers who contribute greatly to the financial strength of the broadcast stations. So quality assurance is to take into consideration the audience factor which is as crucial to broadcasting as programming.

\section{Issues of Quality Assurance in Broadcast Style and Content}

It is pertinent for us to note that some issues are considered universal, as such, every society gives them considerable attention.According to Watson and Hill (1993) cited in Ugande (2005); issues are those social, cultural, economic or political concerns or ideas which are, at any given time, considered important and which are the sources of debate, controversy or conflict. What is an issue for one social group may not be considered as such by another. Therefore, the critical issues at stake in this paper are quality assurance in broadcast style and content.

To buttress the writer's argument, the views of two seasoned journalists in print and electronic media are represented here. Firstly, the National Mirror of Thursday, April 4, 2013, reported the $8^{\text {th }}$ anniversary of Unilag FM, where Mrs. Eugenia Abu, Deputy Director, Training 
and Capacity Building, Nigeria Television Authority (NTA), said, "I have been largely disappointed over the years by the way in which professionalism within the broadcast industry has been thrown to the dogs. But I am getting ahead of myself." She spoke on the topic: "Professionalism in Contemporary Broadcasting: The Way Forward for Campus Radio and Television Stations in Nigeria."

She stated that what is killing broadcasting at most broadcast stations is Reality TV, which is impacting negatively on young people because it is about back-stabbing. On faulty hiring of most personnel in the broadcast industry, she said: "Let us take our young broadcasters today who because they are not properly processed by their establishments arrive on the scene very green as we all did, but they are unleashed on the hapless public within two weeks without any training. A good voice is not necessarily a professional broadcaster; there are processes of becoming one."

Mrs. Abu does not consider herself a star. She says she is a public figure or just a role model. She pointed out that: "we put the cart before the horse. A lot of young people come in to become stars in two weeks and deepen their illiteracy. Most people join because they want to become stars." She lamented the deplorable state of professionalism in the broadcast industry and recommended that broadcasters should acquire more training for the demanding job of broadcasting.

The veteran newscaster, motivational speaker and media strategist said that: "a professional broadcaster is one who is skilled in his task, good at communication, good at analysis, an expert at interviewing, has good judgment, has a good sense of fair play, is sensitive, is polite and understands how to report a tragedy. She stressed that a broadcaster does not form an opinion on air or has his own, but delivers the facts accurately with a sense of social responsibility and then allows the public to form their own. He is also an agenda-setter, allowing his audience to follow an issue of great national concern." She emphasized that the broadcaster with a professional pedigree helps to shape national policy by affecting it positively and bringing the people's voices to bear in matters of national interest.

Secondly, the Saturday Sun of April 20, 2013, published an interview of Mr. Nosa Igiebor, Editor-in-Chief of Tell Magazine and Broad Street Journal, who lamented the dearth of quality reporting in both the print and electronic media. "Unfortunately, these days either in our newspapers or magazines or even broadcast media, you hardly see any effort geared towards serious reporting. That, to me, is very sad." He said the journalist plays a constructive role in the governance of the country. He recommended ingenious but legitimate ways to improve the image of the journalist, his profession as well as boost the revenue base of journalism practice in Nigeria. He pointed out that journalism practice is "dangerous and therefore every journalist must have a life insurance cover; not just a life insurance cover, but the one that can provide adequately for that person's family, in the event of his demise. It is a good initiative by all journalism external bodies in Nigeria. And I think it is one initiative that should be vigorously pursued and implemented across the entire industry."

From the above discussions, we have brought to the front burner the issues of moral and professional distress in the media industry which affect quality assurance in broadcast style and content. In another vein, in the Leadership newspaper of April 25, 2013, an article titled, How Journalism Students can Thrive in Knowledge-Driven Economy, Mr. Ezra Ijioma, observed that: "As the internet shapes and reshapes physical and social realities, journalists have to learn and unlearn media skills not just for filing stories but for delivering media contents and engaging the individual and mass audiences. Media organizations continue to face the dilemma of reallocating resources to attract new readers and viewers while still trying to hold on to their existing, and usually aging, print or broadcast audiences. The digital technology presents an 
often bewildering variety of choices for journalists and survival requires understanding all these new technologies and how to utilize them. This is the burden of the aspiring and experienced journalists."

Obi (2012), observes that public attitude to the Nigerian broadcast industry, especially TV stations, is that of lassitude and weariness due to what some of them described as boring programmes. Although, most TV viewers have the choice to remain with the boring TV programmes or go for a pay TV with multi-channels, they cannot afford it, a situation that has imposed no other option than viewing terrestrial TV station.

Another issue that affects quality assurance in broadcast style and content is the "indignant commercialization of news by these TV and radio stations" thereby raising great concern to the public. "Almost every corporation's news and events are seen by these stations from commercial perspective." An industry watcher states that: "It is the job of all the news media to tell the people what is going on in their community - locally, nationally or globally. In this sense, the news media provide a valuable public service."

A media analyst argues that if everything is said to have commercial news value for the broadcast industry, do the stations then air proper news? What is the thin line between news and commercial news? If they have more commercial news than what they consider as proper news in a day, will there be news that day, he asks. When the broadcast industry, "especially TV stations, charge corporate organizations to report their events and programmes," it is unethical and goes against the basic concept of what is news

The broadcast industry in Nigerian is today faced with multi-faceted challenges from the profession itself, which according to Zayyan (2013), is low in Nigeria as employment is not necessarily incumbent upon qualification, skill or merit but rather is often a function of the patronage consideration. The challenges are so many that it can take a decade to elucidate. Digitization is perhaps the most intimidating or fazing challenge of all those facing our broadcast media. This is so because over time there has been a lot of confusion in the country due to ignorance. Unfortunately even the media do not give the process the proper publicity. Mr. Zayyan stresses that: "basically, the essence of this process called digitization is to enhance sound and picture quality and to also make multi-channel viewing easily accessible. It represents the most significant innovation since the advent of television itself. No doubt digital terrestrial broadcasting will affect all segments such as content production, transmission and reception."

Mr. Zayyan reminds us that by the year 2015, all television sets owned by Nigerians and the world over will cease to operate; these sets will be obsolete unless otherwise a digital settop box decoder is used or new television sets were bought by television viewers through pay TV subscriptions. The implication to this switch over is that most Nigerians are unaware of this situation and many do not know that their fantastic television sets may no longer be in vogue in 2015. He emphasizes that broadcasters equally know that for successful transition, they need to overcome the challenges of digitally non-compliant studio equipment, content provision, new coverage planning, training for its personnel and public awareness.

Sunmonu (2013), believes that when fully implemented, digital broadcasting would go a long way in enhancing the nation's broadcast industry in terms of quality in audio and visual input. Stakeholders are of the view that a more advanced, value-laden digital technology would enable consumers, especially those in the rural communities, explore the opportunities of quality broadcast signals and choice channels numbering up to one hundred on their television sets.

Umeibe (2013), reports that one of the many advantages of the digital migration would be the availability of more radio frequency spectrum for broadcasting, thereby providing 
opportunity for more programming content and channels to the viewers. As the digital migration draws near, he says it is pertinent for stakeholders and regulators to properly identify and establish proper guidelines for channel/contents acquisition and distribution. His opinion is that emphasis should be on providing more quality contents and channels to Nigerians at an affordable or better still no cost, rather than pay- TV operators striving to lockdown channels and contents exclusively to their platforms, thereby depriving millions of Nigerians who do not subscribe to their services of quality content. He states that TV viewing is not a social class thing, and should not be encouraged as such. The more quality information is made easily accessible to Nigerians, the better our society and the economy. Quality assurance in broadcast style and content can project our positive values and image of Nigeria to the world.

Finally, the National Broadcasting Commission and Broadcasting Organization of Nigeria should provide a level playing- ground for operators in the broadcast industry and enforce strict compliance with the institutional, legal and regulatory framework.

\section{Conclusions}

The advent of liberalization of the broadcast media industry has brought some gains in terms of creativity and expansion of the media enterprise yet there are still areas of improvement especially in quality assurance. The emergence of private broadcast stations is a formidable challenge to the dominance of the Federal Radio Corporation of Nigeria (FRCN) and Nigeria Television Authority (NTA) over the years. Healthy competition among public and private media outfits is necessary to improve the quality of broadcasting content and coverage, to positively affect the lives of listeners and viewers. A competitive broadcast media will enhance operations and improve the image of the industry. Also broadened scopes of broadcasting, sustained entertainment and public service programmes that cut across political and tribal divides will enhance and consolidate democracy, and promote good governance and economic development.

In spite of the futuristic vision of the potential of the digital technologies, we cannot ignore the many powerful social, economic and political factors which preserve the traditional broadcast media. No matter how far and fast the digital revolution and convergence go, the long traditions and vast expertise in providing mass information and entertainment will guarantee that broadcasting continues be the centre of developments.

Those who can anticipate the huge changes the broadcast industry will experience in the coming years can adapt traditional broadcast practices to meet such challenges.

Broadcasting will continue to be an area of widespread popular discussion and political controversy because of its enormous influence, and because it is near the centre of wider developments.

Despite concerns with budgets, programme costs, viewing figures and ratings, "broadcasting still retains its place as a subject of national interest, national concern, and government intervention". In future there will be exciting times in the broadcast industry even as changes in broadcasting over the last twenty years have been much affected by new digital technologies in satellite and broadband cable. However, the new wave of technological developments will not see the end of broadcasting but, transform it as a distinct activity.

Perhaps, there will be a convergence - a merging of broadcasting, telecommunications and computing industries into one big digital information industry, which would involve film, print publishing and video games. 


\section{Recommendations}

In order to give vent to quality assurance in broadcast style and content, the following recommendations are made: As the Executive, Legislature and Judiciary are institutions which mediate relations between the individual and the state, so the mass media should mediate relations between the governed and the government by ensuring that best practices and standards are orientated to the satisfaction of society.

The broadcast industry must strive to achieve excellence in programming, uphold the tradition of professionalism and preserve values and ethics in its reportage. There should be a structured on-the-job programme to train broadcasters to develop their voices and improve their diction and standardize their first language interference on accent and pronunciation.

The broadcasting profession should have established rules on broadcast programmes, methods of addressing and communicating with their audience. Broadcast programmes like game shows, soap operas, drama series, talk shows and news bulletins are distinct from each other, yet belong collectively and distinctly to the activity of broadcasting. Professionalism means producing these programmes according to constantly rising standards of technical and artistic quality in broadcast style and content. In addition, broadcast media should be conscious of broadcasting's public service ethos, and observe the principle of impartiality, objectivity, balance and fairness in matters of political controversy and religious difference.

The British Broadcasting Corporation (BBC) editorial values of truth and accuracy, impartiality and diversity of opinion, editorial integrity and independence, serving the public interest, fairness and openness, respect for people's privacy and protection of children and being accountable to the audience are also worthy of note.

\section{References}

[1] Goodwin. P. (2000), Media Careers Broadcasting.Television and Radio Broadcasting: Past, Present and Future. Purple House Limited, Oxford, London.

[2] Hornby A.S (2000), Oxford Advanced Dictionary Of Current English. Oxford University Press, London.

[3] Oketunmbi, E.(2007). Gains and Pains of Liberalization of Broadcasting in Nigeria: A Critical Assessment. Journal of Communication and Society 1(2\&3).

[4] Sambe. J. A. (2008), Introduction to Mass Communication Practice in Nigeria. Spectrum Books Limited, Ibadan, Nigeria.

[5] Ugande. G. A. (2005), Issues in Broadcasting : An Introduction. Culture Media Nig. Ltd, Makurdi, Nigeria.

[6] Ugande. G. A. (2009), Broadcast Programming.Segabus Publications, Makurdi, Nigeria.

[7] Copyright National Broadcasting Commission (2007-2011) The History of Broadcasting in Nigeria. http://www.city.org/: Retrieved on April, 2013.

[8] Obi, D. Commercial News in Nigeria's Broadcasting Industry: http://www.cityu.org/: Retrieved on April, 2012.

[9] Rouse, M. (2007), Quality Assurance Definitions: http://www.cityu.org/: Retrieved on May, 2013.

[10] Umar, J. (Oct, 2008) Amplifying the People's Voices: Community Broadcasting in a Digital Era. Retrieved on April, 2013.

[11] Way Forward for Broadcasters: National Mirror, Thursday, April 4, 2013. Vol. 3, No. 592, P. 46. 
[12] Quality Reporting is in Decline: Saturday Sun, April 20, 2013. Vol.10 No. 538, P 18-20.

[13] How The Media Can Thrive in Knowledge - Driven Economy: Leadership, Thursday, April 25, 2013. No. 1598, P 31.

[14] Broadcasting and the 2015 Digital Compliance Deadline: Vanguard, Thursday, Aug, 22, 2013. Vol. 25: No 61952, P. 6-7.

[15] Analogue to Digital Broadcasting: Preparation for 2015 Date. Nigerian Tribune, Thurs. 29 Aug. 2013. No. 15795. P. 24

[16] P. O. Simeon, B. Ambah, International Letters of Natural Sciences 2 (2013) 1-10.

[17] P. D. Kaze, K. P. Gam, International Letters of Natural Sciences 2 (2013) 11-18.

[18] Y. A. Aliyu, I. J. Musa, T. T. Youngu, International Letters of Natural Sciences 2 (2013) 19-30.

[19] Ebad Bashiri, Jahanbakhsh Bashiri, Farhad Karimi, International Letters of Natural Sciences 3 (2013) 7-20.

[20] Goran Rajović, Jelisavka Bulatović, International Letters of Natural Sciences 3 (2013) $1-6$.

[21] Ebad Bashiri, Jahanbakhsh Bashiri, Farhad Karimi, International Letters of Natural Sciences 3 (2013) 7-20.

[22] L. U. Grema, A. B. Abubakar, O. O. Obiukwu, International Letters of Natural Sciences 3 (2013) 21-27.

[23] H. T. Oladunjoye, N. Olasunkanmi, A. O. Olaleye, International Letters of Natural Sciences 3 (2013) 28-38.

[24] Hyginus A. Nwona, International Letters of Natural Sciences 4 (2013) 1-9.

[25] Alamu Salawu Abideen, International Letters of Natural Sciences 4 (2013) 26-33.

[26] Bernice N. Chukwu,Veronica O. Ezebuiro, E. S. Samuel, Keyna C. Nwachukwu, International Letters of Natural Sciences 4 (2013) 34-43.

[27] A. N. Obilonu, C. Chijioke, W. E. Igwegbe, O. I. Ibearugbulem, Y. F. Abubakar, International Letters of Natural Sciences 4 (2013) 44-53.

[28] Tomáš Hes, Anna Poledňáková, International Letters of Social and Humanistic Sciences 2 (2013) 18-31.

[29] Mohsen Mehrara, Masoumeh zirak, International Letters of Social and Humanistic Sciences 2 (2013) 32-38.

[30] Taiwo Adewale Muritala, Ismail O. Fasanya, International Letters of Social and Humanistic Sciences 2 (2013) 39-50.

[31] Borowski A., International Letters of Social and Humanistic Sciences 3 (2013) 46-53.

[32] Borowski A., International Letters of Social and Humanistic Sciences 3 (2013) 69-74.

[33] Donovan A. McFarlane, International Letters of Social and Humanistic Sciences 4 (2013) 35-44.

[34] Rajesh K. Yadav, Nishant Dabhade, International Letters of Social and Humanistic Sciences 4 (2013) 49-69.

[35] Borowski A., International Letters of Social and Humanistic Sciences 4 (2013) 70-74.

[36] Paul Bukuluki, International Letters of Social and Humanistic Sciences 5 (2013) 27-44.

[37] Mohsen Mehrara, Maysam Musai, International Letters of Social and Humanistic Sciences 5 (2013) 55-62.

[38] Debiprasad Mukherjee, International Letters of Social and Humanistic Sciences 6 (2013) 41-48.

[39] Tomáš Hes, Alena Neradová, Karel Srnec, International Letters of Social and Humanistic Sciences 7 (2013) 55-75. 
[40] Kinga Dziwańska, International Letters of Social and Humanistic Sciences 7 (2013) 96-112.

[41] Borowski A., International Letters of Social and Humanistic Sciences 7 (2013) 113-118.

[42] Mohsen Mehrara, Maysam Musai, International Letters of Social and Humanistic Sciences 8 (2013) 1-7.

[43] Jacek Tittenbrun, International Letters of Social and Humanistic Sciences 11 (2013) 10-34.

[44] Mohsen Mehrara, Hamid Abrishami, Mostafa Boroujli, Mahan Amin, International Letters of Social and Humanistic Sciences 11 (2013) 76-83.

[45] Borowski A., International Letters of Social and Humanistic Sciences 11 (2013) 100-105.

[46] Sele Sylvester Ebisin, International Letters of Social and Humanistic Sciences 2 (2014) $1-9$.

[47] Tittenbrun J., International Letters of Social and Humanistic Sciences 2 (2014) 20-40.

[48] Borowski A., International Letters of Social and Humanistic Sciences 2 (2014) 110-121.

[49] Pawa Tersoo, International Letters of Social and Humanistic Sciences 3 (2014) 26-36.

[50] Rabi'u Muhammad Ishaq, International Letters of Social and Humanistic Sciences 3 (2014) 37-44.

[51] Adoga James Ada, International Letters of Social and Humanistic Sciences 3 (2014) 45-52.

[52] Bahram Meihami, Hussein Meihami, International Letters of Social and Humanistic Sciences 3 (2014) 80-91.

[53] Kabiru Ibrahim Yankuzo, International Letters of Social and Humanistic Sciences 4 (2014) 1-8.

[54] Onyike Maggaret Odu, International Letters of Social and Humanistic Sciences 4 (2014) 31-39.

[55] Uloma Charity Oguzor, International Letters of Social and Humanistic Sciences 4 (2014) 97-104.

[56] Okezie A. Ihugba, Alex Odii, A. C. Njoku, International Letters of Social and Humanistic Sciences 5 (2014) 21-34.

[57] Okezie A. Ihugba, Bankoli Bankong, N. C. Ebomuche, International Letters of Social and Humanistic Sciences 5 (2014) 92-113.

[58] Borowski A., International Letters of Social and Humanistic Sciences 6 (2013) 86-90. 